\title{
Energy and transatlantic relations: The attempts to establish a European energy policy on the eve of the 1973 oil crisis
}

\author{
Silvio LABBATE
}

The world oil shock of 1973 marked a critical moment in the field of international relations. The embargo, for instance, shaped the world's industrial governments especially the Western European cabinets - and this had a significant bearing that altered to some extent their foreign policies towards the Arab-Israeli conflict, which often clashed with the United States (US) interests. ${ }^{1}$ The first signs of what happened in the first oil crisis were considered as being tangible in preceding years. For example, the American idea to create a consumers' front against the oil producers - mainly towards the Arab countries - started a long time before 1973. Although in this circumstance the European partners did not give the right importance to the American warnings - not considering the imminence of an oil crisis - the US-European cooperation was a constant in the energy sector.

In addition, the 1973 oil shock was a defining moment for the continuation of both the European integration process and the development of continental energy co-operation. With the exception of some circumstances, it is not possible to identify the fundamentals of European energy policy before this even. ${ }^{2}$ Nonetheless, if real cooperation in this field only matured after 1973, developments in the decade afterwards arose from past strategies. In fact, energy was one of the main sectors of European co-operation (as shown by the third part of the Spaak Report), to the extent that, in their early stages, the integration process and European energy collaboration developed together.

The purpose of this paper is to analyse the evolution of the main transatlantic relations in the energy sector on the eve of the oil crisis, starting from the attempts to establish a European energy policy. There is extensive literature on the oil shock, the reasons leading to the embargo and its consequences, but few texts focus on the USEuropean countries' energy co-operation on the eve of the 1973 crisis.

\section{The thwarted co-operation: The first steps of the European energy policy}

After the Second World War, the European countries felt the need to co-operate in every productive sector in an attempt to improve the future of the whole continent.

1. For Western European governments the author refers to the European Economic Community (EEC) governments.

2. For European energy policy the author refers to the attempts to create collaboration in this sector among Belgium, France, Federal Republic of Germany, Italy, Luxemburg and the Netherlands (also including United Kingdom, Ireland and Denmark from 1973). 
During that period, studies on atom and its uses were one of the first examples of European collaboration after 1945. In these circumstances, an interesting debate arose about the possibility of uniting all continental forces in order to fill the technological gap between Europe and the United States, where research was at an advanced stage. ${ }^{3}$ This subject was also at the core of several meetings, such as the Congress of Lausanne (8-12 December 1949). On that occasion, it was suggested to create an international laboratory of research, with the aim of joining minds and resources in this strategic field. These developments can be considered the first steps towards starting of co-operation in the nuclear energy sector after 1945 and, therefore, a prelude to the creation of European Atomic Energy Community (EURATOM) and Conseil Européen pour la Recherche Nucléaire (CERN), the world's greatest laboratory for the study of particle physics. ${ }^{4}$

After signing the institutive treaty of the European Coal and Steel Community (ECSC) in Paris on April 1951 and continuing with the European integration process, EURATOM was established for the purpose of co-ordinating common research programmes related to nuclear energy. ${ }^{5}$ The idea of setting up a European Community for the peaceful use of atomic energy followed the definitive failure of the European Defence Community (EDC) and, in that phase, it represented an important tool for the support of European integration. ${ }^{6}$ The aim was to achieve European energy independence through the atomic source so as to solve the enduring lack of the so-called "traditional energy", which was one of the main problems of the 1950 s. $^{7}$ The decision to unite the efforts at a community level was also the result of the costs of the investment exceeding the possibilities of single states. The aim of the institutive treaty was to contribute to the formation and development of the European nuclear industry to guarantee the safety of energy provisioning. At the same time, the agreement reassured the population of the fact that atomic supplies would be destined for civil rather than military purposes. After an earlier agreement reached at the Venice Conference in 1956, the institutive treaty was signed in March 1957 with the European Common Market (ECM) treaty in Rome. The energy question appeared in the third part of the Spaak Report; this section contained a series of recommendations on the

3. See J. KRIGE, American hegemony and the postwar reconstruction of science in Europe, The MIT press, Cambridge, 2006.

4. About the events and the discussions on European scientific co-operation during the years following the Second World War cf. L. BELLONI, Da Fermi a Rubbia, Rizzoli, Milano, 1988, pp.8-94.

5. See A. VARSORI, P.L. BALLINI (eds), L'Italia e l'Europa: 1947-1979, Rubbettino, Soveria Mannelli, 2004; É. NOËL, Le istituzioni delle Comunità europee, Ufficio per l'Italia della Direzione generale stampa e informazione delle Comunità europee, Roma, 1972.

6. About the US support of the EURATOM project $\mathrm{cf}$. G. SKOGMAR, The United States and the nuclear dimension of European integration, Palgrave Macmillan, Basingstoke, 2004; J. HELMREICH, The United States and the Formation of Euratom, in: Diplomatic History, 3(1991), pp.387-410.

7. The aim of achieving European energy independence through the atomic source nevertheless did not exclude international co-operation in the sector. In fact, in 1953 the President of the United States Dwight D. Eisenhower proposed the creation of an international corporation to both regulate and promote the peaceful use of atomic power (nuclear power), in his "Atoms for Peace" address to the UN General Assembly. 
measures considered urgent, and energy was the first. ${ }^{8}$ Therefore, the European countries had also undertaken to set some proposals for a European energy policy when the institutive treaties of the EEC and EURATOM were signed. ${ }^{9}$

Notwithstanding, considering the matter in a wider geographical and political context, the main problem affecting the European countries was still securing a safe and independent energy supply. It was certainly the Suez crisis that finally pointed out the risks of a possible break in energy supplies, due to the interruption of Middle East naval routes. This event forced the European countries to undertake immediate actions; three high-level experts, the so-called "Three Wise Men" of the EURATOM, namely French Professor Louis Armand, German Professor Franz Etzel and Italian Francesco Giordani created a special Committee. The Committee had the task of introducing a programme for the installation of nuclear-power plants in Europe, which had to balance both the demand for a safe energy supply and the reaching of an affordable economic cost for the European countries. ${ }^{10}$ After series of consultations, in May 1957 the Committee presented a report entitled "An objective for the EURATOM", considered as the real programmatic manifesto of the new atomic institution of the Community. The report established the electronuclear power level for all the 15,000 MW plants to be built in Europe by 1967, guaranteed by the construction of approximately 100 new nuclear average-dimension power plants. ${ }^{11}$ In addition to this strategic way, collaboration between Washington and European Communities in the energy sector improved with the May-June 1958 agreement on the peaceful uses of atomic energy. ${ }^{12}$ It concerned the exchange of information in the field of fast reactors between the European Atomic Energy Community and the United States Atomic Energy Commission (USAEC), showing the fundamental connection between the two sides of the Atlantic. ${ }^{13}$

8. B. CURLI, Le origini della politica energetica comunitaria, 1958-64, in: M. GUDERZO, M.L. NAPOLITANO (eds.), Diplomazia delle Risorse. Le materie prime e il sistema internazionale del Novecento, Polistampa, Firenze, 2004, p.98. A few months later, a secret protocol of agreement was reached between the EURATOM Council of Ministers and the High Authority, which had the task of producing some proposals to start a community energy policy. The first consequence of this protocol was the creation of a "Mixed Energy Committee" that formed the "Inter-Executive Energy Committee".

9. Nevertheless the nuclear European project clashed with the French military intentions; for close examinations. L. NUTI, La sfida nucleare. La politica estera italiana e le armi atomiche, 1945-1991, Il Mulino, Bologna, 2007, p.120.

10. B. CURLI, L'Italie et l'EURATOM: l'attitude des hauts fonctionnaires et des experts, in: E. DU RÉAU (ed.), Europe des élites? Europe des peuples? La construction de l'espace européen, 1945-1960, Presses de la Sorbonne nouvelle, Paris, 1998, pp.277-289.

11. F. IPPOLITO, Un progetto incompiuto. La ricerca comune europea: 1958-88, Dedalo, Bari, 1989, pp.68-70.

12. Accord de coopération entre la Communauté Européenne de l'Énergie Atomique (EURATOM) et le gouvernement des États-Unis d'Amérique concernant les utilisations pacifiques de l'énergie atomique, in: Journal Officiel des Communautés Européennes [JOCE], 17(1959), pp.309-311.

13. HAEU [Historical Archives of the European Union], File Edoardo Martino, 222, Text of the arrangement concerning exchange of information in the field of fast reactors between the EURATOM and the United States Atomic Energy Commission (USAEC), non dated. 
However, from the 1950s, studies on European energy co-operation focused on another problem that would become crucial in the following years: the necessity of relying on a secured energy supply for the European countries at an affordable cost. This new outlook was a further step towards a real European energy policy during the 1960s. Thus, the European Parliament approved a Resolution on 20 February, 1962 that listed the basic principles of this common target: supply of cheaper raw materials, their progressive replacement, stability of the provisioning in the long term, consumers' free choice and unity of the common market. Following this action, the EEC Council of Ministers instructed the Commission to gather some concrete proposals on 5 April. Then, the Inter-Executive Energy Committee drew up the "Memorandum on energy policy" on 25 June 1962, which was the first real step toward a European energy policy. ${ }^{14}$

On the other hand, energy co-operation could also represent a starting point for the continuation of the European process of integration provided that an effective community energy program had been carried out. ${ }^{15}$ On this basis, in February 1966, the Commission of the European Communities transmitted to the Council of Ministers a Memorandum on the Community's policy for petroleum and natural gas, which can be considered a fundamental step forward towards the realization of a Community energy policy. This document pointed out that, in the application of the Rome Treaty, all the national energy objectives would be due to be replaced, before 1970, with those decided in the Community sphere. It was a bold position that had always been hindered by the Federal Republic of Germany, Belgium and partly France, which were against a Community energy policy without limits, despite the favourable position of Italy and the Netherlands. ${ }^{16}$ The carboniferous interests of Paris, Bonn and Brussels pushed their opposition to whatever norm able to limit domestic production and the national sovereignty over every energy source. In spite of these different interests among the member States - at least up to that moment - the position slowly changed after the outbreak of the Six Days' War when, in order to punish the friends of Israel, some Arab countries resorted to an oil embargo through the closing of the Suez Canal. Although this kind of measure (the so-called oil weapon) was the first attempt to condition the choices of Western countries, the consequences had been below expectations. This was due to the brief duration of the oil boycott and the abundant national reserves of the United States, which were the principal target of such an action. ${ }^{17}$

14. AEI [Archive of European Integration], Energy Policy in the European Community, Inter-Executive Energy Committee's Memorandum (High Authority of the European Coal and Steel Community, European Community Information Service), Brussels, 25.06.1962, Internet Website http:// aei.pitt.edu/34492/1/A662.pdf.

15. See Protocol of Agreement on energy problems, reached between the Governments of the Member States of the European Communities, Luxemburg, 21.04.1964, in: JOCE, 69(1964), pp.1099-1100.

16. AEI, Memorandum by the Commission to the Council on the Community's policy for petroleum and natural gas, 16.02.1966, Supplement to Bulletin No 7-1966 of the EEC, Internet Website http:// aei.pitt.edu/30726.

17. D.YERGIN, The Prize. The Epic Quest for Oil, Money and Power, Simon \& Schuster, New York, 1991, pp.479-498. 
Nevertheless, this event caused a series of debates about the opportunity to change the current energy-policy strategy. On the one hand, there were those who, in a farsighted way, pushed for an alternative energy source, while on the other, there were those who focused on minimizing the Arab attempts. The main target of the former was to call for further development of nuclear energy, while the latter seemed more favourable to promoting real supranational energy policies in order to create strong bonds, especially economic bonds, among the associated countries. Whatever the strategy chosen, a common action would have been important, as suggested by the United States. Instead of following this path, the EEC countries put different strategies into effect, not considering the possible risks linked to the oil supply from the Middle East. The period did not seem to be enough mature for the development of a unitary Western strategy. In fact, energy policies inside the Western countries were very different: some European States - as Italy - were still completely dependent on oil importation from the Mediterranean area. ${ }^{18}$ Although they had roots in the European Coal and Steel Community in 1951, and subsequently in the EURATOM in 1957, the European countries were not able to create a real energy policy. The inadequacy of European collaboration in this sphere was the consequence of the attitude of the member States' national governments, which were reluctant to abdicate their sovereign prerogatives in this specific sector, even though the European integration process had considered the role of energy as very important since its origins. Therefore, without a real collaboration inside the European countries it was very difficult to start an energy transatlantic co-operation. On the other hand, until the Six Days' War the American wish to start collaborating with Europe in this field did not seem to be a priority. This occurred especially in the oil field where, except for some rare exceptions, the market was dominated by the so-called "seven sisters" or "big seven", the Anglo-American companies that, prior to the 1973 oil crisis, controlled as much as 85 percent of the world's petroleum reserves. More than collaboration, US desired to maintain the control of the energy sources market.

Nevertheless, the international oil market had undergone a significant adjustment in 1960, when several oil-producing countries decided to unite to gain greater control over the production and price of their oil: Iraq, Iran, Kuwait, Saudi Arabia, and Venezuela came together to form the Organization of the Petroleum Exporting Countries (OPEC). OPEC's members were concerned that although they provided 80 percent of the world's oil, they had no control over how much the Western oil companies paid them for it. OPEC's aims were openly in contrast both with the seven sisters' interests and, consequently, with the US oil policy; in addition to this scenario, Arab oil-producing states were naturally sensitive about the American friendly policy towards their public enemy Israel. For this reason, during the Six Days' War the Arab OPEC countries resorted to an oil weapon in order to condition the choices of the Western nations and to punish the Israel-allied States. Furthermore, the end of the

18. About Italy, cf. S. LABBATE, Il governo dell'energia. L'Italia dal petrolio al nucleare, 1945-1975, Le Monnier, Firenze, 2010; Id., Italy and the development of the European Energy policy: from the dawn of the integration process to the 1973 oil crisis, in: European Review of History, 20(2013), pp.67-93. 
Bretton Woods system in 1971 damaged even more the relations between oil producing countries and US: since crude was priced in dollars, this meant that oil producers were receiving less real income for the same price.

The situation on the oil market changed radically in the first half of 1970 when, after a long period of stability, prices of the main oil products showed big rises. This circumstance could be attributed mainly to the cumulative influence of a number of events affecting the world energy market and partly to the effects of the inflationary trends in the economy. Firstly, pressures at the beginning of 1970 conditioned the American market, where the energy supply could not meet the demand. In addition, two events affecting crude oil availabilities in the Mediterranean occurred in mid-1970: the Trans-Arabian Pipeline (TAPLINE), which carried part of the Saudi Arabian production to the Mediterranean, was closed in May; then, the Libyan government imposed production restrictions, in some cases amounting to 50 percent on certain operators. Although the total effect of these two developments was confined to comparatively minor quantities of oil, this situation underlined the extent to which the oil products market was exposed to outside influences. ${ }^{19}$

\section{Transatlantic relations and energy issues}

The US-European countries' relation was - and still is today - one of the most important bilateral relations in the world. Nonetheless, the two had regularly disagreed on a wide range of specific issues, as well as having quite often different political, economic, and social interests. In the course of the years, numerous historical events caused clashes between US and Europe. These events included the 1956 Suez crisis, when a degree of resentment of the European allies, caused by a perceived US betrayal, led to the British withdrawal from the colonial Empire; the 1962 Cuban missile crisis, which alarmed Western Europeans not only because it almost led to a nuclear war, but also because they were not fully appraised by the Kennedy administration; the Vietnam war, opposed by political and public opinion in Western Europe, and which generated resentment in the US because of the lack of European support; the end of the Bretton Woods system in 1971, brought about by the Nixon administration without reference to Western European leaders. This last event in particular caused big problems in the EU economic systems, therefore determining huge incomprehension in transatlantic relations. All these happenings were proof of the latent European criticism to Washington hegemony in transatlantic relations. ${ }^{20}$

Moreover, the US-European countries' background co-operation was never challenged in the least; it included many areas such as trade and military policies, but the

19. AEI, The situation on the energy market in the Community, October 1970, Information Memo P-43/70, Internet Website http://aei.pitt.edu/30086/1/P_43_70.pdf.

20. T.L. ILGEN, Hard Power, Soft Power, and the Future of Transatlantic Relations, Asgate Publishing Limited, Burlington, 2006, p.27. 
main question was still focused on the difficulty for Europe to establish a unique foreign policy. This circumstance created serious problems to the American diplomacy, which had desired a single European interlocutor for a long time. For instance, Europe's difficulties represented a huge problem for Henry Kissinger and his ideas on international relations; while Richard Nixon's administration concentrated its efforts to conclude the Vietnam War, the European countries seemed to deal only with internal integration issues. On the other hand, Europe considered the détente as an endless source of restlessness: Europeans saw the United States as too preoccupied about their relations with the Soviet Union and bitterly complained about the lack of consultations. ${ }^{21}$ Then, transatlantic relations had perhaps reached their lower point since the years of the Suez crisis; in this context also the outbreak of the Watergate scandal played an important role. ${ }^{22}$ Then the White House considered 1973 as the year of the turning point. In fact, after having finally concluded the conflict with Vietnam and completed the opening in China, Washington decided to focus on the improvement of transatlantic relations. For Kissinger, 1973 had to become "the year that never was" or simply the "Year of Europe". ${ }^{23}$

Notwithstanding, as seen, transatlantic relations adopted a new course on energy issues after the Six Days' War. Although European countries still had problems to create a real continental energy policy, Washington started to consider the importance to co-operate in this sector more. Consequently, the risk of a new possible threat by the Arab oil producing countries made the beginning of a closer co-operation between the United States and the European partners more urgent. ${ }^{24}$ This had been the advice of the American experts since January 1971, after having analysed in detail the international energy market and its weak points in the United States. According to a report sent to Kissinger by Philip H. Trezise, chairman of the Interagency Oil Task Force, the present world oil situation involves the likelihood of a significant increase

21. A.G. ADRIANOPOULOS, Western Europe in Kissinger's Global Strategy, Macmillan Press, London, 1988; R. SCHAETZEL, The Unhinged Alliance. America and the European Community, Harper \& Row, New York, 1975.

22. See H.A. KISSINGER, Years of Renewal, Simon \& Schuster, New York, 1999, p.600; Id., Years of Upheaval, Little, Brown \& Company, Boston-Toronto, 1982, pp.72-127.

23. H.A. KISSINGER, The Year of Europe, in: The Department of State Bulletin, 14.05.1973, pp. 593-598; see also M. GILBERT, Gli anni Settanta: un decennio di tensione e disattenzione nelle relazioni transatlantiche, in: M. DEL PERO, F. ROMERO (eds), Le crisi transatlantiche. Continuità e trasformazioni, Edizioni di Storia e Letteratura, Roma, 2007, pp.45-64; C. HYNES, The Year that Never Was: Heath, the Nixon Administration and the Year of Europe, University College Dublin press, Dublin, 2009; D. MÖCKLI, Asserting Europe's Distinct Identity: The EC Nine and Kissinger's Year of Europe, in: M. SCHULZ, T.A. SCHWARTZ (eds), The Strained Alliance. U.S.European Relations from Nixon to Carter, Cambridge University Press, New York, 2010, pp. 195-220.

24. After all, the past US studies about the effects of oil problems in the transatlantic relations were very clear: "Our NATO allies are thinking of making direct deals with governments of oil producing countries if oil deliveries are further curtailed". See FRUS [Foreign Relations of the United States], 1969-1976, vol.XXXVI, Energy Crisis, 1969-1974, Action Memorandum From the Deputy Assistant Secretary of State for International Resources and Food Policy to the Assistant Secretary of State for Economic Affairs, 28.07.1970, pp.117-122. 
in the payments made by oil-producing countries - and consequently increased costs to the consumers and the oil companies - and the possibility of interruption or cutback in supplies imposed by some of the OPEC countries. ${ }^{25}$ Therefore, in spite of the European energy problems, Americans were worried about the international oil situation: the first US issue was the avoidance of serious disruption in the economies of the Western countries due to either an interruption of supply or a very large and sudden increase in the cost of oil. ${ }^{26}$

Nevertheless, in this stage the European partners seemed to not give the correct importance to the American warnings, not considering the imminence of an oil crisis. ${ }^{27}$ In fact, although they discussed the possible problems of oil provisioning, the necessity to co-operate with Washington in the energy field was not on the agenda. Actually, for Franco Maria Malfatti, the third President of the European Commission from 1970 to 1972, the necessity to prepare a European strategy in case of energy crisis had to start from the revaluation of carboniferous resources. Instead, in case of oil provisioning problems - not considered imminent - there was the need, on one side, to establish new relations with the oil exporting countries and, on the other side, to provide the Community with technical tools able to attenuate the possible consequences of the crisis. An important role had to be attributed to nuclear energy, while the relations with the oil exporting countries had to become of interdependence. Therefore, for the President of the European Commission there was no urgency as regards an oil crisis; moreover, Malfatti did not think about the necessity to collaborate with Washington in the energy field: Europe's main concern was access to oil. ${ }^{28}$ After all, in the matter of oil supplies a lot of differences existed among the Europeans. The Netherlands and the United Kingdom (UK) had companies which possessed adequate resources for their needs; other EEC countries such as Germany and Italy, instead, depended largely on US firms to meet their needs; in the end, France had its own concessions and controlled imports in order to diversify its sources of petroleum. However, the continent was heavily dependent on the Arab world for oil, and this posed a potential problem, but at the moment Europe continued to control sufficient oil to supply its needs and therefore there were no particular worries.

25. NARA [National Archives and Record Administration], NPMP [Nixon Presidential Materials Project], NSSM [National Security Study Memorandum], World Oil Situation. Memorandum for Mr. Henry A. Kissinger From Philip H. Trezise, Chaiman of Interagency Oil Task Force, 25.01.1971. About Trezise's point of view see: P.H. TREZISE, The Atlantic Connection. Prospects, Problems, and Policies, Brookings Institution, Washington, 1975.

26. On the other hand, as Richard J. Barnet argued, the end of cheap oil cast doubt on the political and economic assumptions of the postwar order. Cf. R. BARNET, The Alliance. America, Europe, Japan: makers of the postwar world, Simon \& Schuster, New York, 1983, p.327. About transatlantic relations see also: L. KAPLAN, American Historians and the Atlantic Alliance, Kent State University Press, Kent, 1991; D. RYAN, The United States and Europe in Twentieth Century, Pearson Education, New York, 2003.

27. See FRUS, 1969-1976, op.cit., Embassy in the Netherlands (Bovey) to the Department of State, 20.10.1970, pp.134-136.

28. AEI, Speech by President [of Commission] Malfatti before the Consultative Committee of the ECSC, 13.07.1971, Internet Website http://aei.pitt.edu/13784/1/S79.pdf. 
In January 1971, the Americans were still optimistic about the possibility of avoiding oil interruptions or cutbacks, because there were strong common interests shared among the producing countries, the companies and the principal consumers. But they recognized that the long-term objective of at least several producing countries governments was the progressively greater control over production and, eventually, the nationalization of oil operations. These assumptions probably sprang from the recent OPEC meeting at Caracas (7-12 December 1970) where the minimum tax rate was settled at 55 percent and the requested posted prices reflected the foreign exchange rates. For Trezise, if these demands were not satisfied there would have been the risk of a short or long-term interruption of supplies imposed by some OPEC countries. ${ }^{29}$ The American worries arose from three recent events which were likely to alter the negotiations between the oil producing countries and the oil companies: the Arab-Israeli war which closed the Suez Canal in June 1967; the emergence of Libya as one of the leading oil producers in the late 1960s, and following the takeover of the radical regime in 1969; the closure of the TAPLINE in May 1970 by Syria. ${ }^{30}$ All these events contributed to a true "tanker" market. This deprived the oil companies of most of their previous flexibility to shift among different sources of supplies such as the Caribbean, the Persian Gulf and North Africa.

In this new scenario the American experts analyzed any possible evolution of the oil world market. They foresaw what would happen in case of shutdowns or disruptions of oil supply as early as the beginning of 1971. The impact on Western Europe could have depended not only on the amount of oil denied, but also on the duration and circumstances of the denial. But the main question was the outcome of the cooperation among the oil companies and among the consuming countries. The US, amid the other objectives, would have owed:

"To maintain constructive political relations with producing countries; $[\ldots]$ in the Middle East, to keep separate the Arab-Israeli disputes and the oil problem, by treating the latter as essentially an economic matter; to ensure that the oil problem [will] not cause strains and misunderstandings in the US relations with Europe and Japan; to insure that oil supplies cannot $[\ldots]$ be used as a political weapon against the US and its allies". ${ }^{31}$

Therefore, contrary to the European partners, Washington was very careful in taking into account the risks of a possible oil crisis and to consider the principal consequences on transatlantic relations. The keeping of good relations with Europe was considered a primary aim. In 1972, after Washington's specific request, the European Commission began considering the hypothesis to co-operate with US in the energy field in order to avoid a possible oil crisis. ${ }^{32}$

29. NARA, NPMP, NSSM, World Oil Situation, Memorandum for Mr. Henry A. Kissinger From Philip H. Trezise, Chaiman of Interagency Oil Task Force, 25.01.1971.

30. A. NOUSCHI, Pétrole et relations internationales de 1945 à nos jours, A. Colin, Paris, 1995, p. 35.

31. NARA, NPMP, NSSM, Memorandum for Mr. Henry A. Kissinger..., op.cit.

32. HAEC [Historical Archives of the European Commission], BAC 156/1990, 521, Remarque sur le Rapport Akins, 28.02.1972. 
Nonetheless, as far as security aspects were concerned, the American experts sharply analysed two points of view on the implications of the world oil situation for the security of the United States and its system of alliance. For the first one, the United States and the other NATO countries had long recognized the security risks inherent in their collective heavy dependence on the Middle Eastern and the North African oil, which loomed so large in world production and reserves that there was no substantial substitute for it, at least in the immediate future. Consequently, beyond the period covered by stocks, there was little hope for the maintenance of the Western European economies without access to major parts of the Middle Eastern and the North African oil supply. Furthermore, with the enormous growth of energy consumption in the United States, Europe, and Japan, and with some deterioration of the US excess capacity and reserves related to the amount of its consumption, America could not provide enough petroleum to its Allies to off-set major cut-offs on the Middle Eastern and the North African oil, even after taking necessary action to mobilize its resources. The other view argued that the security aspects of the present situation, as outlined above, were overrated. In fact, according to the US, the difference between the parties involved was essentially the over-price, and the strong interest in keeping on the present lines of trade would have produced an agreement without great risks of serious disruption. The main assumption was that the producing countries had no other market for their oil (they also needed revenues from its selling) and the consuming countries had to import it without any other foreseeable oil source.

In both views the US-European countries' relations remained very important with regard to a potential oil crisis. In fact, the fear of severe oil shortages for Europe could become politically divisive. These were the possible hypotheses:

"One or more Western European consumers (and Japan) might break ranks, possibly threatening a general rush to execute government-to-government supply agreements that would undercut our oil companies. - European consumers could attempt to seek further access to Soviet oil as a means of reducing dependence on the unstable Middle East, given the lack of spare capacity in the US [...]. - Our European allies, already somewhat out of step with the US on this issue, would increasingly question our policy towards the ArabIsraeli dispute and would become more receptive to Arab-favoured solutions of the conflict". ${ }^{33}$

Although these assumptions were considered remote at that time, the detailed analyses of the American expert suggested the United States had to act immediately to face any eventuality. In addition to the national choices in energy policy (above all more investments in the nuclear sector), the United States had to assist Europe in case of shutdowns or disruptions of oil supply, as far as possible.

In this context, on 14 February 1971, the Tehran Agreement was signed between the oil companies and the Persian Gulf host governments: it established the progressive increase of the oil prices up to 1975 and a greater decisional power from the producing countries governments. Then, the international oil market began to have

33. NARA, NPMP, NSSM, Memorandum for Mr. Henry A. Kissinger..., op.cit. 
deep transformations that gradually changed the old rules. ${ }^{34}$ Even though, after this agreement, the world's petroleum consuming countries thought they could look forward to some years of relative stability in the world's oil market, OPEC countries started to make new demands for part ownership in the operations of the oil companies. And failure to reach some arrangement on the participation issue could well lead to a significantly reduced role for international oil companies in the production end of the oil business. Therefore, in meetings of the Organization for Economic Cooperation and Development (OECD) Oil Committee and in bilateral discussions with European partners, US' delegates constantly pointed out the importance of maintaining consumer solidarity in the face of OPEC demands and urged them to increase their stock levels as a form of protection against supply cut offs. ${ }^{35}$ Moreover, on 20 January 1972 the Persian Gulf members of the OPEC and the foreign oil companies operating in those countries agreed to a substantial increase in posted prices of petroleum. The increase was officially designed to restore to the oil producing countries the purchasing power lost because of the dollar's devaluation. Instead, the other OPEC members (Algeria, Indonesia, Libya, Nigeria, and Venezuela) had already increased their prices individually or were expected to do so in the near future. The final agreement was signed in Geneva: it increased the posted prices of Persian Gulf crude exports by 8.49 percent. ${ }^{36}$ The international oil market needed therefore new actions to avoid further threats; on the other hand, the Arab States now controlled two-thirds of the world's proven oil reserves through the OPEC cartel.

According to another memorandum designed for the President, drawn up by the Secretary of State William P. Rogers (10 March 1972), the United States would have produced a little more oil by 1980 than in 1972, while consumption would have risen. Then the position of NATO Allies and Japan would have been even more precarious. For this reason, the European allies had already been urged to raise the levels of their strategic stocks of petroleum to give them at least some degree of flexibility in dealing with the producing countries. For Rogers, the most important item was the achievement of a common action among consumers in the OECD countries. Subsequently, the United State asked Canada, Japan, the UK and the EEC countries to examine with them "the feasibility of vastly increased co-operation in the development of both conventional and non-conventional energy forms". ${ }^{37}$ There were a lot of discussions with European and Japanese allies about the prospects of co-operating to find and develop new sources of energy and avoid the competition for available energy in

34. Cf. G. LENCZOWSKI, The Middle East in World Affairs, Cornell University Press, Ithaca-London, 1980, pp.214-215; W.J. LEVY, Oil Strategy and Politics, 1941-1981, Westview Press, Boulder, 1982, pp.180-195; L. MAUGERI, L'era del petrolio. Mitologia, Storia e futuro della più controversa risorsa del mondo, Feltrinelli, Milano, 2006, pp.127-128; J. STORK, Il petrolio arabo, Rosenberg \& Sellier, Torino, 1978, pp.166-171; D. YERGIN, op.cit., pp.574 and 582-583.

35. FRUS, 1969-1976, op.cit., Briefing Memorandum From the Acting Assistant Secretary of State for Economic Affairs to the Under Secretary of State, 18.01.1972, pp.254-256.

36. Cf. FRUS, 1969-1976, op.cit., Intelligence Memorandum Prepared in the Office of Economic Research, Central Intelligence Agency, February 1972, pp.264-268.

37. Ibid. Cf. also NARA, Subject Files, Energy Crisis, The US and the Impeding Energy Crisis, 09.03.1972. 
times of crisis, but "their responses varied from scepticism to enthusiastic approval". ${ }^{38}$ This proved how much different the positions in the transatlantic relations were and, above all, those inside the European Community.

In the same period, James E. Akins, entrusted with the oil issues by the US State Department, drew up a report for the President regarding the American oil supply. For Akins,

"there are those in some consuming countries (e.g. Italy, France and Spain) who believe that the only way their security can be preserved is to develop a new direct relation with the producing countries which would bypass the 'Anglo-Saxon' oil companies, and therefore avoid the consequences of any action the Arabs might take against the United States". ${ }^{39}$

To avoid this situation and to guarantee the US oil supplies, Akins attributed an important role to the OECD. This report was also sent to the European Commission, which emphasized the opportunity to increase collaboration with the United States; the possibility to "constitute an 'International Petroleum Advisory Group' to help the American government for the survey of the oil international problems" was assumed.

The necessity of co-operating with the allies was also the core of a further memorandum for Kissinger (11 July 1972). In fact, the members of the National Security Council (NSC) Staff, Robert D. Hormats, Richard T. Kennedy and John D. Walsh analysed the case of the energy crisis in political terms: "We reckon that the oil problem has political ramifications of direct and fundamental importance to US foreign policy - and will increasingly do so in the years ahead". The most important development pointed out was an emerging Arab capacity to financially sustain a total embargo on oil shipments over a protracted period: "The growing financial reserves of Middle East producers have made oil a weapon for coercion or blackmail that we can no longer dismiss". For the members of the NSC Staff this shift in power introduced a new factor into the Arab-Israel equation focused on creating the potential for serious Arab pressure on the US and its principal allies:

"Moreover, since European and Japanese dependence on Middle East oil will continue to be far greater than ours, effective Arab leverage will increasingly represent a divisive factor in overall relationship with our allies and points to further divergence of views on the ArabIsraeli situation".

In this context, the prospects of an enhancement of the Soviet pressure and influence should have been taken into account because Moscow could become an alternative to the Arab oil, offering "secure" supplies to Europe and Japan. In fact, the American fear of Russian supplies was felt a lot; but perhaps this possibility was already contemplated by US State Department as a collateral outcome of the détente. On the other hand, the political implications for the US alliance relations suggested the need for a serious attention to oil policy: "As an increasingly import-dependent consumer, the

38. Cf. FRUS, 1969-1976, op.cit., "Impeding Energy Crisis and Means to Meet It", Memorandum of Conversation, 22.05.1972, pp.295-297.

39. HAEC, BAC 156/1990, 521, Remarque sur le Rapport Akins, 28.02.1972. 
US must also weigh carefully the pros and cons of the 'energy bloc' approach reflected in pressures for Western Hemisphere preferences". 40

The Washington pressure on the European partners achieved a degree of success in October. In fact, analysing the necessary progress in Community energy policies, the Commission decided to co-operate more with US and others importing countries in this field:

"Energy supplies are thus already a worldwide problem, and in future will be even more so. No country and no group of countries, however great its geographical, economic or political importance, can solve this problem alone".

Therefore, the Commission suggested that the Council should regularly arrange talks on energy questions with the United States, Japan and other interested countries; moreover, it was recommended to improve the existing OECD procedure in order to provide better reciprocal information concerning both problems and proposed solutions, and to work out joint decisions on security and stock building, which could also be applied to those countries outside the European area of the OECD. ${ }^{41}$ In fact, it was admitted that Energy issue could be so grave that purely national solutions of its many aspects were inadequate and inadvisable and a co-operative approach was essential. Afterward, at OECD meeting in October, Fernand Spaak, Director general for Energy of European Communities Commission and European delegate to the High Level Group of the OECD Oil Committee spoke for the entire Community, and therefore, responded for first time with one voice: ECC admitted the Washington urgency for a co-operative approach to energy problems. ${ }^{42}$ Inside the European partners, British and Germans gave Spaak strong support and Italians urged quick action to meet problems. High Level Group agreed to appoint working group to make quick résumé of energy problems and finish the work before March, with High Level Group meeting sometime in February to review conclusions and study means of meeting methods of co-operative actions to meet problem. The Europeans for the first time jointly expressed their desire to co-operate with US on broad front to solve energy problems, but this was alone the first footstep of a long and eventful route.

Furthermore, after a careful analysis of the energy problems, Walter J. Levy, the international oil advisor and consultant to the US State Department, suggested an alliance of petroleum consumer nations:

"The power of the producing countries is increasing fast [...], and rising demand for oil in the consuming countries will increasingly place them at the mercy of the producing countries. [...] While the US and UK are better placed than Japan and the rest of Western Europe in respect of indigenous fuels [...], both will gain more than they lose by uniting

40. NARA, NPMP, NSSM, Foreign Policy Ramifications of US Oil Policy, Memorandum for Kissinger From Robert D. Hormats, Richard T. Kennedy e John D. Walsh, Members of the National Security Council Staff, 11.07.1972.

41. AEI, Communication From the Commission to the Council, 04.10.1972, Internet Website http:// aei.pitt.edu/5146/1/5146.pdf.

42. Cf. FRUS, 1969-1976, op.cit., Deputy Secretary of State (Irwin) to the Department of State, 25.10.1972, pp.363-364. 
with the other consuming countries to work out ways of reducing their dependence on Middle East oil and the damage which the producing countries could do to their economies by misusing oil revenues. Neither the US by itself, nor the EEC by itself are of a sufficient size to "go it alone"".

For Levy, an Atlantic/Japanese alliance of consumer countries was necessary to realize a co-ordinated and stable free world energy policy, to counterbalance the potential disruptive power of the producing countries and to ensure, as far as possible, that the revenues of oil producing countries were "channelled into sensible international development projects rather than into disturbing the economies of the West and the international monetary system". ${ }^{43}$ The alliance prospected by the Consultant to the US State Department might have the form of an "International Energy Council", with a permanent staff and an expert Commission of investigation and conciliation. But this approach

\begin{abstract}
"commanded little support from other government departments, principally on the grounds that it would get governments too directly involved in detailed oil negotiations and in any case would be unlikely to commend itself to a number of potential members because it would shore up the dominant position of the US major oil companies". ${ }^{4}$
\end{abstract}

\title{
Energy as "potential divisive issue"
}

Any alliance implied good liaisons among all the parties involved, but in 1972 the US relations with Western Europe entered a transitional stage; there were several issues still open such as the political, military and economic situations in Europe and beyond. For instance, the strategic equivalence between the US and USSR sparked concerns about the US commitment to Europe's defence, especially after the signature of SALT I agreement, which raised questions among the allies about the US nuclear guarantee. At the same time, several developments in the US policy created uncertainties and concerns among the Western Europeans: Congressional efforts to reduce US forces in Europe increased concerns with domestic issues, balance of payment problems, budgetary stringent measures, the appearance of a growing isolationism and protectionism. And, for the first time, in a memorandum for Kissinger drawn up by Walter J. Stoessel, Jr. Assistant Secretary for European Affairs (18 December 1972), the energy policy was recognized as a potential divisive issue between the EEC and US:

"Given the large US stake in the European energy market in both trade and investment terms, it is in our interest to avoid a competitive scramble for limited oil resources and to

43. Reports W. Levy's proposal for an alliance of oil consumers to R. Marshall 12.12.1972, in: K. HAMILTON, P. SALMON, The Year of Europe: America, Europe and the Energy Crisis, 1972-1974, Documents on British Policy Overseas, Series III, vol.IV, Routledge, Oxon, 2006, doc.5.

44. Minute between George B. Chalmers (Head of Oil Department) and George S. Whitehead (Assistant Under-Secretary of State, FCO), 14.12.1972, in: K. HAMILTON, P. SALMON, op.cit.,doc.6. 
reach a broad understanding with the Western Europeans on a co-operative approach to the long-term energy problem and on arrangements to share supplies in the event of an emergency".

For Stoessel, a co-ordinated policy would have had to include not only an agreement on supply policies but also an agreed approach to technical solutions for the energy question, the development of alternative energy sources, the improvement of environmental control, the increased efficiency of power production, the use and the institution of methods to conserve energy. ${ }^{45}$

Really there were the risks of possible oil blackmails and a general awareness on the necessity of a greater international collaboration on energy matters. These took place after the OPEC agreements (signed on December 21, but not from Iraq) that provided for 25 percent government ownership of all Western oil interests operating within Kuwait, Qatar, Abu Dhabi and Saudi Arabia beginning on 1 January 1973 and rising to 51 percent by 1 January 1983. Then, Levy's thesis - the increasing negotiation strength of the producing countries vis-à-vis the oil companies - was admitted. For instance, oil issues were included by the British Oil Policy Committee: in fact, they were among the points of the British Prime Minister's discussions with Richard Nixon during his forthcoming visit to the United States (1-2 February, 1973). ${ }^{46}$ During the first meeting, the US President asked Edward Heath when did he think the oil and gas from the North Sea would make a real contribution to Britain's energy requirements. Oil had been discovered in onshore areas around the North Sea during the previous century, while natural gas was found in 1910; the production from this area would have required an entirely new generation of technology. But British Petroleum announced the discovery of oil in the Forties field on the British side at the end of 1970. It was a huge reservoir and new discoveries followed in the same area during the following year: now a new generation of technology was either available or under development in order to improve the production in the North Sea. ${ }^{47}$

For this reason, based on Levy's worries, the US President wanted to verify the availability of these new energy resources in case of shutdowns or disruptions in traditional oil supply. Heath said they could be available only by the mid-80s: "It was the years in between which were the problem, for in that period we should be in a weak position in relation to the great oil producers". 48 The British Prime Minister's answer was surely predicted by Nixon but he probably just wanted to understand if there was the awareness about a possible risk of blackmail in Europe by the producing countries. The energy policy was in fact one of the principal issues of the following meeting between the two leaders. Nixon and Heath agreed on two possible different approaches: the creation of "an effective major consumers front against the pro-

45. NARA, NPMP, NSSM, US Relations with Europe, Memorandum for Kissinger From Walter J. Stoessel, Jr. Assistant Secretary for European Affairs, 18.12.1972.

46. Record of meeting of Oil Policy Committee, 24.01.1973, in: K. HAMILTON, P. SALMON, op.cit., doc.16.

47. Cf. D. YERGIN, op.cit., pp.574 and 667-670.

48. Record of discussion: Heath/Nixon, 01.02.1973, in: K. HAMILTON, P. SALMON, op.cit., doc.19. 
ducers" that would have "at least restrain[ed] their more maverick members from breaking ranks", or a direct confrontation with the producer countries by "a co-ordinated body of consumers" that would have tried "to divide them by arranging for the consumers to come to separate bilateral arrangements". ${ }^{49}$ But the period was not mature enough for a similar choice, so Nixon and Heath postponed this issue to future meetings.

These debates proved that in this period Europe and above all the United States were warned against the risk of a possible oil crisis. In a memorandum drawn up by the British Secretary of State for Trade and Industry, Peter E. Walker, a further confirmation can be found. In accordance with this analysis on the international energy market, in the next future there would have been a very large increase in the oil import requirements of US and Japan, mainly from the Middle East. The competition for supplies would have encouraged producers to hold consumer countries in a political and economic blackmail in case of a worsening of the relations or an intensification of the Arab-Israeli conflict. Therefore the increasing wealth of some of the oil producers and the fears of others about the duration of their reserves would have brought further restrictions on production with the sharp rise of energy prices. Consequently, Walker sketched out how the American companies, if the oil supply position became tight, might have begun to pursue an "American first" policy:

"They already have a dominant position in Saudi Arabia, the largest exporter of the [...] OPEC, and with by far the largest potential. There is now a tendency for Saudi Arabia to be regarded as the US' preferred source of crude and the two countries have developed close political links in which guaranteed oil supplies are probably a key factor". ${ }^{50}$

Indeed many countries (above all the United States) had already planned a strategy in case of emergency, even before the beginning of the oil crisis, and the bilateral agreements, which gave rise to a clash between Washington and its major European allies after October 1973, were fully considered. However this approach did not exclude the necessity of a greater international co-operation in the energy field, as stressed in Levy's thesis. The most appropriate forum for co-ordinating oil consumers' policy was the OECD - as required by a large number of countries -, which included all the major importers. Furthermore, its Oil Committee had successfully operated the emergency oil sharing arrangement during the first Suez crisis in 1956. But up to that moment, partly due to its semi-public nature and wide membership, OECD had found it impossible to go beyond supply sharing and the exchange of information. For this reason, the possibility of a new, tailor-made organization of oil importing countries and companies was also examined in order to co-ordinate government and company policies in dealing with OPEC. On the other hand, there were also a lot of arguments against the creation of such a formal association.

The EEC Commission recommended instead that consumer governments should act jointly on the purpose of broadening their economic links with OPEC members,

49. Record of discussion: Heath/Nixon, 02.02.1973, in: K. HAMILTON, P. SALMON, op.cit., doc.21.

50. Memo by P.E. Walker for Cabinet Ministerial Committee on Economic Strategy, 08.02.1973, in: K. HAMILTON, P. SALMON, op.cit., doc. 23. 
in the view that a wider range of interests would promote greater stability in oil issues. Commission, which claimed to be the most qualified actor to start direct contacts with the producing countries since it represented one of the greatest oil consumers areas, suggested offering them financial aid, technical assistance, increased commercial credit and special support for major projects..$^{51}$ In addition, on 19 April 1973 the EEC Commission sent a communication to the Council entitled "Orientations et actions prioritaires pour la politique énergétique communautaire", in which the necessity of beginning a profitable international co-operation in the field of energy was affirmed, starting from a "climat de confiance" with the Middle East energy suppliers. ${ }^{52}$ The necessity of starting a "climat de confiance" with the energy suppliers became a central point of the guidelines of the Community energy policy; some Western countries started to find a solution in connecting the import of oil to the support of financial initiatives in the oil-exporting countries for the purpose of tiding up their affairs and economies. ${ }^{53}$ However, this approach did not exclude collaboration with the other oil consuming countries, above all the United States. Moreover, a lot of OPEC countries increased oil posted prices by 5.7 percent on 1 April and by 11.9 percent on 1 June; this led to a heated debate over energy matters.

On its part, EEC, in spite of the inadequacy of the partners' collaboration in this sphere, tried to develop an energy policy in order to gain certain and lasting supplies under satisfactory economic conditions. Like the entire West, the Community heavily depended on imported oil, taking about 85 percent of its supply from the Middle East and Africa where the sellers' position was strong. Consequently, it would have been very convenient for Europe to promote co-operation among oil consuming countries (including the United States and Japan) in dealing with exporting countries. ${ }^{54} \mathrm{In}$ fact, in April, the collaboration between the ECC and energy importing countries (especially with Washington and Tokyo) definitely became a priority of the Community energy policy. ${ }^{55}$ On this ground, some secret Anglo-American negotiations - promoted directly by Nixon and Kissinger in March - started. For the Special Assistant of the US President for National Security Affairs, an energy crisis and lack of a common political and diplomatic initiative was the first external factor that could jeopardize transatlantic relations:

51. Cf. HAEU, File Edoardo Martino, nn.27-28, Report on the EEC action for the year 1972 submitted by the Italian Foreign Minister, 15.01.1973.

52. Cf. HAEU, File Emile Noël, n.81, Orientations et actions prioritaires pour la politique énergétique communautaire, Communication de la Commission au Conseil, 19.04.1973.

53. These applications were not granted by the EEC Council, but few months were enough to demonstrate their validity. See Archives of the Council of European Union, Intermediate Archives, 12136, Council Directive to Mitigate the Effects of Difficulties in the Supply of Crude Oil and Petroleum Products, Council of the European Communities, 19.07.1973.

54. Memorandum by the Central Policy Review Staff (CPRS) for the Cabinet Ministerial Committee on Europe, 03.04.1973, in: K. HAMILTON, P. SALMON, op.cit., doc.58.

55. Guidelines and Priority Actions under the Community Energy Policy, Brussels, 19.04.1973, in: Bulletin of the European Communities, Supplement 6/73, Internet Website http://aei.pitt.edu/ 1520/1/energy_SEC_73_1481.pdf. 
"If the US, Japan and the countries of Western Europe act in close co-operation with one another, this problem will not only be easier to solve, but the measures taken to this end will powerfully reinforce the unity of the West. The consequences of cut-throat competition for scarce supplies among these major consumers could threaten the stability of the present international balance".

The prospect of an energy crisis was not considered the greatest factor in East/West relations, but troubles with the oil supplying countries of the Middle East could change Moscow's posture in the forthcoming years. In addition, if the Western European governments were in competition with the US for access to the Arab fuel sources, the Soviet Union could use its position as a potential fuel supplier. ${ }^{56}$ In other words, the energy problems had become a strategic issue in transatlantic relations a long time before the 1973 oil crisis.

\section{The eve of the oil crisis}

Henry Kissinger, during his famous speech of 23 April which officially opened the "Year of Europe", stated that the United States were "prepared to work co-operatively on new common problems we face, energy, for example, raising the challenging issues of supply assurance, impact of oil revenues on international currency stability, the nature of common political and strategic interests, and long-range relations of oilconsuming to oil-producing countries. This could be an area of competition: it should be an area of collaboration". ${ }^{57}$ This call for the US and Europe to work together with Japan on the solution of such problems, including the energy issue, reflected the Americans' desire to maintain the closest political, economic and defence co-operation among its Allies. ${ }^{58} \mathrm{But}$, as it is known, finding a compromise for collaboration in time of peace is always easier rather than during a crisis. On the contrary, Kissinger's initiative further deteriorated the transatlantic relations; as he wrote in his memories, the 'Year of Europe' "came to be viewed [...] as an American stratagem to thwart the re-emergence of a specifically European identity and institutions". ${ }^{59}$ The Watergate scandal muffled the trust of US initiative. Indeed, as the signs of the possible new Arab-Israeli war became more evident, the co-operative scenario rapidly collapsed.

The necessity for a more urgent collaboration with the allies was already stressed at the beginning of June in a memorandum for Kissinger drawn up by Philip A. Odeen, Chairman of the ad-hoc Committee on the International Aspects of Energy for OECD

56. The next ten years in East-West and transatlantic relations. Note by B. Trend (Secretary of Cabinet), J. Hunt (Second Permanent Secretary) and H.F.T. Smith (Deputy Secretary, Cabinet Office), 12.04.1973, in: K. HAMILTON, P. SALMON, op.cit., doc.65.

57. Washington to the Foreign and Commonwealth Office, 23.04.1973, in: K. HAMILTON, P. SALMON, op.cit., doc.70.

58. Cf. H.A. KISSINGER, Years of Upheaval, op.cit., pp.128-194 and 700-746.

59. H.A. KISSINGER, Years of Renewal, op.cit., pp. 600-602. 
meetings. Odeen analysed the US leverage for the co-operation with Europe and Japan in the energy matters. His conclusions pointed out America's dominant position and the allies' weakness in managing energy matters without the United States. This leverage stemmed from several factors: first, the US had a considerable economic and political influence on Saudi Arabia and Iran, the two richest oil nations, which accounted for over 30 percent of the world's cheapest reserves. Moreover, these countries had to make considerable production increases if worldwide oil needs were to be met through 1980. For this reason, it was unforeseeable that the proper economic environment could be created without America's participation. And even though the Saudis were to meet the required levels of production, they would have had the necessity of a stable general economic environment for investment opportunities. In accordance with this analysis, Kuwait had already reduced the oil production because they do not need oil earnings to meet domestic objectives and the Saudis could do the same. Thus, in order to reduce the likelihood of this event, the US could provide investment opportunities and proper economic institutions. The second element of Washington's leverage was derived from technological advantages. The US was the only major consumer nation with such domestic resources at its disposal that could reduce its future demands for oil imports:

"Development of our more costly domestic alternatives could substantially relieve future tight oil markets and without US demand (about 30-40 percent of the total) the OPEC countries could find it difficult to maintain prices at the current level of 10 to 15 times cost. On the other hand, if we decide to compete for foreign oil rather than develop domestic alternatives, the allies will find it hard to meet their own needs and will pay a higher cost. Thus, our efforts to develop domestic energy resources and other alternatives to the Middle East oil provide the other consuming countries with influence they would not otherwise have in counter to the OPEC countries".

Both the comparatively large domestic oil reserves and the access to Canadian and Venezuelan supplies made the US far less dependent on imported oil than European countries or Japan. Odeen analysis also pointed out factors that could impair the US leverage. For instance, if there had been a Saudi Arabian embargo or an Arab embargo on oil sales against the Americans only (in the context of an Arab-Israeli conflict), the Europeans might not have believed in the necessity of co-operation or in any emergency import sharing plan.

Nevertheless, the most critical area of political co-operation with Europe was in joining the efforts aimed at improving consumer country market position vis-à-vis the producers. In that moment it was hard to criticize the general concept of consumer nations' co-operation; but the real issue was the nature of the co-operative effort and the feasibility of a closer co-operation among the major consumers. For Odeen, there were differences in the various co-operative approaches:

"In Europe, the French are dragging their feet and have thus far prevented the European community from developing a firm position on co-operation. The French, Italians, and Germans are each going their separate ways seeking their own sources and the British are hoping that the North Sea oil will solve their problem. The Japanese, who are 100 percent 
dependent on foreign oil, have strong interest in co-operation, yet feel very vulnerable and are deeply concerned over the risks".

The Americans were consequently well aware of the possible future scenarios. The most obvious concern was that the efforts to develop a "counter cartel" would have hardened the attempt of the producer countries to break up the co-operative arrangement. And "even if a co-operative agreement [was] created, the first oil crisis or price negotiation [would] create pressure for each country to make separate deals". On the other hand, despite the aforementioned problems, if co-operative efforts were going to be successful, "the US must play a key role. This provides us considerable leverage with the allies who are aware of the need for co-operation but surely need US leadership". ${ }^{60}$

Collaboration with the other oil consuming countries was also an item in Nixon's Energy Message; the note the President sent to the Congress in April, in which he announced the phasing out of oil import quotas and asked for legislation on a number of other energy matters designed primarily to increase indigenous energy supplies. Nixon's main concern was raising US dependence on oil imports, but he pointed out the desire to work with the allies in energy matters, especially with European partners.$^{61}$ Nixon's intentions were explained by Julius Katz, Deputy Assistant Secretary of State for International Resources and Food Policy of the US State Department, during a meeting held at the Foreign and Commonwealth Office:

"It was important for countries with similar problems to concert their actions as far as possible. They must have an understanding on oil sharing in times of emergency though it would be difficult to work out the details, such as what conditions would constitute an emergency situation. [...] We must try and avoid a scramble for available oil supplies".

Nonetheless, it was very difficult in that moment to decide how to come up with the long-term problem of co-operation between consumer and producer countries because none of the approaches seemed to be appropriate. For Katz, the US government would not have been in favour of either a cartel of consumers or a special organization since this solution could bring only disadvantages. On the contrary, he was in favour of a more frequent bilaterally consultation either in-group or within OECD. ${ }^{62}$ But inside the EEC there were already different points of view and it was also very difficult to co-ordinate the energy policy of the various European partners. Even if there was a warning on the risks of a possible oil crisis in Europe, they still did not believe it possible so early. Therefore, although co-operation with the oil importing countries had become a priority of the Community energy policy, not a lot was done to carry out this guideline.

Consequently, according to NSSM 174 Report of August, classified by Odeen, "energy has become a potentially divisive issue, which could further strain US al-

60. NARA, NPMP, NSSM, Memorandum for Kissinger from Philip A. Odeen, 06.06.1973.

61. Cf. F. PARRA, op.cit., pp.168-170.

62. Anglo-US oil talks, Record of meeting held at the Foreign and Commonwealth Office, 06.11.1973, in: K. HAMILTON, P. SALMON, op.cit., doc. 118. 
liance relationships with Europe and Japan unless the allies found a common effective approach to the problem". ${ }^{3}$ In another memorandum, the same Odeen was clear even more: "France, Italy, and Germany also appear to be adopting to go it alone policy. $[\ldots]$ The need to avoid the potential competition is acute". ${ }^{64}$ Hence, a few days before the beginning of the fourth Arab-Israeli war, it was well clear that the energy matters could be a severe test for transatlantic relations. On the other hand, nobody thought that the Arab countries' blackmail would have altered the whole future scenario. This circumstance appears fundamental to understand the reasons why nothing much was done before the first oil shock. As for the US-European countries' relations, a motivation in this sense derives from a previous general incomprehension; it seems likely that co-operation in the energy field could have been far more productive in a rosier transatlantic relations scenario.

\section{Conclusions}

When on 16 October Iran, Iraq, Abu Dhabi, Kuwait, Saudi Arabia and Qatar unilaterally raised the posted crude price announcing production cuts, and the following day some OPEC oil ministers agreed to use the oil weapon in Arab-Israeli war, the governments of the whole world were amazed. ${ }^{65}$ The following step was the embargo on oil exports to the United States (19 October) and to the Netherlands (23 October), considered friends of Israel. ${ }^{66}$ In these circumstances, the US confidence in its leverage in conditioning the choices of the transoceanic allies toward a one voice answer to the Arab's blackmail crumbled in front of the desire to resolve the energy shortage with a bilateral agreement policy. ${ }^{67}$ Despite the attempts of Kissinger and Nixon's diplomacy, the greatest part of the unfavourable hypotheses previously formulated by American studies both on the energy and on transatlantic relations became true. Furthermore, after the new Arab sanctions of 5 November (25 percent cut in production, which was below the September levels), the EEC countries adopted a pro-Arab declaration during the Brussels meeting the following day. This choice set Europe in

63. NARA, NPMP, NSSM, NSSM 174 Report, National Security and US Energy Policy, Executive Summary, Classified by Philip A. Odeen, August 1973.

64. FRUS, 1969-1976, op.cit., Memorandum From Philip A. Odeen to Kissinger, 11.08.1973, pp.517-522.

65. H.A. KISSINGER, Years of Upheaval, op.cit., pp.854-934.

66. G. LENCZOWSKI, The Oil producing Countries, in: R. VERNON (ed.), The Oil Crisis, W.W. Norton and Company, New York, 1976, pp.59-72; E.T. PENROSE, The Development of Crisis, in: R. VERNON (ed.), op.cit., pp.39-57; F. VENN, Oil Diplomacy in the Twentieth Century, Macmillan, London, 1986, pp.142-144.

67. H.A. KISSINGER, Years of Renewal, op.cit., pp.664-700. 
a difficult position towards Israel and, above all, the United States ${ }^{68}$ In fact, although the US recognized that the oil difficulties were at the basis of the EEC countries' decisions, Americans could not accept a sharp gap between the two shores of the Atlantic. ${ }^{69}$

Therefore, according to Daniel Yergin "oil weapon [...] altered irrevocably the world as it had grown up in the post-war period" ${ }^{70}$ In fact, the oil crisis seriously affected Europe as a consequence of a set of structural factors that characterized the European economy after 1945. As Robert Lieber argued, the 1973 crisis strained transatlantic relations and the issue of the availability of oil became a matter of "supreme national interest". ${ }^{71}$ After this event and in consequence of US unilateral led in the preceding years, the members of the European Community were persuaded to rethink the relation with its Atlantic partner; in spite of this, Washington maintained its overwhelming influence by using the leverage of military power. Then, even though the oil crisis brought up the issue of a European autonomous course of action in international affairs, the fragmentation among European partners favoured the American unilateral strategy.

Anyway, it is very interesting to observe how some US predictions in the energy field, formulated many months before the 1973 oil crisis, were completely exact. The precision of some prophecies was almost perfect: for instance, the necessity of a narrower co-operation between the United States and the European partners which had been stressed by Philip H. Trezise since January 1971. Hence, almost 3 years before the crisis, the American experts had already foreseen what would happen in case of shutdowns or disruptions of oil supply. In fact, the fear of severe oil shortages for Europe could become politically divisive. At the beginning of 1971, this issue was not classified as urgent, but the analysis of the relations with the allies was a constant feature in all American studies. It was not a coincidence that 1973 had to be the "Year of Europe".

Notwithstanding, as regarding the European side on the eve of the oil crisis there still existed problems in creating a common energy policy. The member States' national governments were still reluctant to abdicate their sovereign prerogatives in this specific sector. Therefore, without a real collaboration within the European countries the energy transatlantic co-operation before the 1973 oil crisis found huge difficulties in taking off. In fact, the first concrete steps of a European energy policy only matured

68. E.B. KAPSTEIN, The Insecure Alliance: Energy Crises and Western Politics since 1944, Oxford University Press, Oxford, 1990; W.L. KOHL, The United States, Western Europe and the Energy Problem, in: Journal of International Affairs, 1(1976), pp.81-96; F. VENN, International Cooperation versus National Self-Interests: the United States and Europe during the 1973-1974 Oil Crisis, in: K. BURK, M. STOKES (ed.), The United States and the European Alliance since 1945, Berg, Oxford, 1999, pp.71-98.

69. TNA, FCO, Philip Adams, British Ambassador in Cairo, to the Foreign and Commonwealth Office, 08.11.1973, in: K. HAMILTON, P. SALMON, op.cit., doc.382.

70. YERGIN, op.cit., p.588.

71. R. LIEBER, Energy, Economics and Security in Alliance Perspective, in: International Security, 4(1980), p.159. 
after the oil shock. The energy transatlantic co-operation increased, with the exception of some circumstances, only after 1973.

Moreover, the US solutions proposed to contrast the increasing influence of some Arab oil producing countries were different but all focused on the creation of a kind of countries' consumer cartel. Under these circumstances, the American leverage could be decisive both to help some allies in dealing with the supplying difficulty and to check the whole energy market. In spite of that, it was clear from the beginning that this cartel could create disappointment above all among some European partners such as France, which had chosen an independent way to resolve the energy shortages a long time before. Consequently, the American desire to collaborate with its allies had to take into account the bilateral agreements that many countries hastened to conclude with the Middle Eastern oil producers. But also the United States had started a series of direct negotiations with some oil producing countries: above all with Saudi Arabia, the largest exporter among the OPEC countries with a huge potential, and with Iran. ${ }^{72}$ But officially, the United States asserted the necessity of a greater international co-operation in the energy field, as they tried to do during the 1973 oil crisis.

At last, despite American studies on the opportunity to improve transatlantic relations that begun several months earlier, nobody could know when and whether the oil crisis would really burst. It was the new Arab-Israeli conflict that led some Arab countries to use oil as a weapon, taking all the Western governments completely aback: in fact, despite the preceding discussions, they had not found a unitary and shared reaction to contrast the oil weapon. Notwithstanding, the ideas contained in the documents analysed in this paper seemed to play a decisive role in the following US-European countries' relations; for instance, the Levy's idea to create an "International Energy Council" to counterbalance the potential disruptive power of the producing countries - proposed almost one year before the crisis - seems to be very similar to the December 1973 Kissinger's proposal "to establish an energy action group [...] for collaboration in all areas of the energy problem". ${ }^{73}$ This last suggestion was the first brick to be laid for the creation of the International Energy Agency (IEA) during the summit of the OECD Council of 15 November 1974 and in accordance with the Washington oil conference conclusions of February 1974. The IEA assignments were: developing a common level of emergency for oil provisioning self-sufficiency; setting up a system of information about the crude international market; creating a long-term program of collaboration to reduce dependence on oil importations; promoting co-operative relations between the oil producing countries and the oil importing States..$^{74}$ In conclusion, the IEA tasks were very similar to the aims that most American documents here analysed tried to realize long before the crisis; therefore, the preceding plans seemed to accelerate - whether not to influence - what the US and Europe actually did in response to the oil shock.

72. Cf. NARA, NPMP, NSSM, Oil Supply Arrangements: Alternative Approaches to the Major Producer and Consumer States, 05.10.1973.

73. TNA, FCO, Alec Douglas-Home, Secretary of State for Foreign and Commonwealth Affairs, to UK Representative in Brussels, 13.12.1973, in: K. HAMILTON, P. SALMON, op.cit., doc.457.

74. See HAEU, File OECD, 32, Decision of the OECD Council, 15.11.1974. 
